Acta Theriologica 38 (1): 93 - 102, 1993.

PL ISSN 0001 - 7051

\title{
Tooth wear and its relation to kind of food: The repercussion on age criteria in Capra pyrenaica
}

\author{
Paulino FANDOS, Jorge F. ORUETA and Yolanda ARANDA
}

\begin{abstract}
Fandos, P., Orueta, J. F. and Aranda, Y. 1993. Tooth wear and its relation to kind of food: The repercussion on age criteria in Capra pyrenaica. Acta theriol. 38: 93 102.

Tooth wear was studied in two Iberian populations of Capra pyrenaica Schinz, 1838. Age-specific variation in type of wear and molar height was compared between sites. Age-specific wear of $\mathrm{M}_{1}$ and $\mathrm{M}_{3}$ was different between the two populations. The relationship of molar height and age (assumed to be wear rate) was also different in each population. The largest differences were found if we consider tooth wear rate as the sum of $\mathrm{M}_{1}$ height + height of mandible. The population of ibex from Gredos appeared to have a much faster tooth wear rate than of Cazorla. The relationship between the results and food types in the different mountain ranges are discussed. A positive relationship was found between tooth wear and the presence of abrasive elements in the diet. Tooth wear appears to be highly population-specific and this implies important consequences for their life history. Our results question the validity of age-determination techniques based on tooth wear for inter-populational comparisons.

Museo Nacional de Ciencias Naturales, José Gutiérrez Abascal, 2. 28006 Madrid, Spain

Key words: Capra pyrenaica, tooth wear, wear rate, age criteria, food, Spain
\end{abstract}

\section{Introduction}

The tooth structure is determined mainly by the genome and the mammalian phylogeny is documented mainly by the fossil teeth (Fortelius 1985). Nevertheless, enamel formation shows distinct functional correlations (Koenigswald 1992), and teeth can be considerated as the part of complex functional and developmental contexts that are not well understood (Fortelius 1985).

The tooth shape is highly heritable and there are many examples of morphological change related to dietary specialisation (Butler 1983). However, there are individual variations as sequential changes, growth or tooth wear that can be used as age estimate method across mammals. Therefore, in mammals, age determination techniques based on teeth can be divided into three main groups:

(1) Sequence of tooth replacement. In this process deciduous teeth are replaced by definitive teeth, according to a specific chronological sequence. Shed of deciduous tooth and sequence of eruption of permanent tooth has often been used 
as a relative age criterion. In the Spanish ibex Capra pyrenaica Schinz, 1838 this method proved to be a good age indicator (Vigal and Machordom 1985), as occurs in other ungulates (Coutourier 1961, Caughley 1965, Chapman and Chapman 1970, Gray and Simpson 1985, Norton and Fairall 1991).

(2) Cementum incremental lines. Accumulation of cement or dentine in the tooth root varies according to the nutritional availability throughout the year producing cementum incremental lines on the root of the tooth. Significant events in the individual's life span such as parturitions, accidents or diseases can also produce cementum incremental lines. This method has been widely used as an absolute age criterion in many mammal groups (Klevezal and Kleinenberg 1969, Kay and Cant 1988, Fandos et al., in press).

(3) Tooth wear. Two kinds of wear have been described: "attrition", which refers to wear caused by the friction of teeth against teeth, and "abrasion", refered to wear caused by the friction between teeth and food (Butler 1972, Fortelius 1985). Wear affects the teeth with a definite pattern. This pattern has been used as a criterion to estimate individual age (Laws 1968, Payne 1973, Miller 1974, Fortelius 1985). Tooth wear is conditioned by intrinsic factors, such as dental structure, eruption sequence, or behaviour (Teaford 1982, Fortelius 1985), and by extrinsic factors, such as type of food (Gordon 1982, McNaughton 1984).

The last papers approach the tooth wear process under different view. Tooth wear has been described as an age-dependent trait (Hall-Martin 1976, Payne 1987, Jachmann 1988, Brown and Chapman 1990, 1991), and the study of the wear process in relation to enamel structures (Boyde and Fortelius 1986, von Koenigswald et al. 1987) and the influence of different food types or food components (cellulose, lignin, silica, phytoliths, etc.) on teeth enamel structure (Walker et al. 1978, von Koenigswald 1992). A few papers have dealt with the consequences of tooth wear on life history strategy (Skogland 1988).

In this paper we attempt to: (1) describe tooth wear as an age related process, and (2) find the relationships between the kind of food and degree of tooth wear in the molar tooth row. Then, we use two skull samples of two populations of Capra pyrenaica: Gredos and Cazorla. The samples were perfectly aged and sexed and there was abundant information about feeding habits (Martínez et al. 1985, Vigal and Machordom 1985, 1987, Fandos 1986, Martínez and Martínez 1987, Martínez 1989).

\section{Material and methods}

We measured the height of the first $\left(\mathrm{M}_{1}\right)$ and third $\left(\mathrm{M}_{3}\right)$ lower molars and the height of corpus mandibulare (Fig. 1) in the two samples of Spanish ibex ( 80 specimens from Gredos and 112 from Cazorla). The Gredos population occurs in a mountainous nucleus in the central part of the Iberian Peninsula, with alpine vegetation. The Cazorla population originates from the SE of the Iberian Peninsula with mediterranean vegetation. All specimens sexed and aged (cementum incremental lines and horn segments; Fandos 1991, Fandos et al., in press) belong to the Scientific Collection of the Unidad de Zoologia Aplicada (Madrid). 

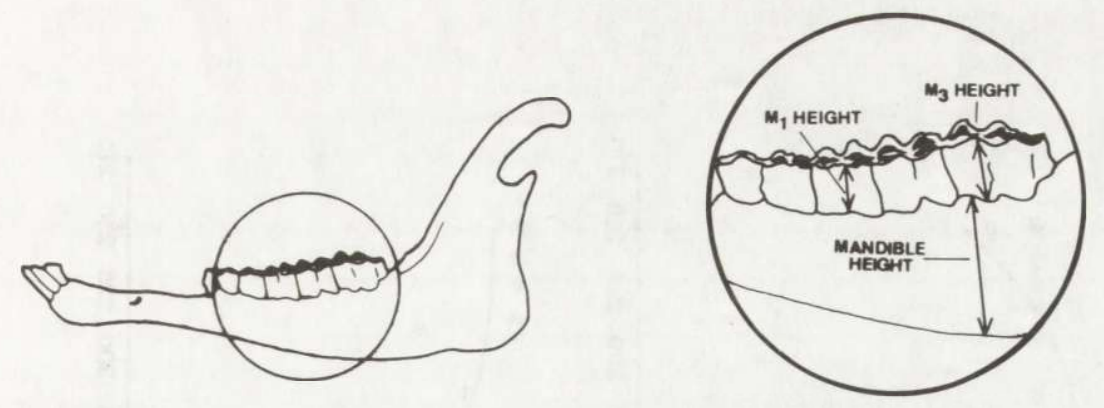

Fig. 1. Description of measurements used.

Tooth wear was estimated using the codes described in Payne (1973, 1987), and by molar height as a wear indicator (Laws 1968, Fortelius 1985, Skogland 1988). The relationships between wear classes, height of molar crown and height of corpus mandibulare with age, are fit to different polynomial regression by the least square method. The differences between populations in functions of tooth wear increases and height of corpus mandibulare are compared using an overall test for coincidental regressions (Zar 1984).

\section{Results}

Basic statistics of the population variables analyzed and the significance of the differences are shown in Table 1.

Table 1. Comparison of $\mathrm{M}_{1}$ and $\mathrm{M}_{3}$ height and height of mandible in two Iberian populations of Capra pyrenaica.

\begin{tabular}{lrrrrrrrrrrrr}
\hline & \multicolumn{4}{c}{ Cazorla } & \multicolumn{4}{c}{ Gredos } & \multicolumn{3}{c}{$t$-Student } \\
& $n$ & $\bar{x}$ & SD & range & \multicolumn{1}{c}{$n$} & $\bar{x}$ & SD & range & df & \multicolumn{1}{c}{$t$} & $p$ \\
\hline M height & 80 & 8.3 & 0.9 & $6.1-10.0$ & 49 & 7.3 & 1.2 & $3.6-9.7$ & 129 & 5.2 & 0.001 \\
M height & 80 & 7.7 & 1.6 & $0.0-11.7$ & 49 & 6.6 & 1.9 & $0.0-10.2$ & 126 & 3.6 & 0.02 \\
Mandible height & 58 & 26.6 & 2.9 & $21.8-32.6$ & 50 & 29.7 & 4.0 & $19.6-35.0$ & 106 & -4.6 & 0.01 \\
\hline
\end{tabular}

\section{Differences in tooth wear classes between populations}

In $\mathrm{M}_{1}$, wear class "14" appears in specimens older than $80-90$ months (Fig. 2). The relationship between wear classes and age fits a polynomial regression. In Cazorla, $y=2.8+0.1 x-(4.3 \mathrm{E}-4) x^{2}(r=0.8, F=78.5$, $\mathrm{df}=2,66, p<0.001$. In Gredos, $y=3.4+0.1 x-(2.6 \mathrm{E}-4) x^{2}(r=0.9, F=102.3, \mathrm{df}=2,47, p<0.001)$. The comparison of polynomial function shows significant difference between the populations $(F$ test $=9.28, \mathrm{df}=2,111, p<0.001$ ).

In $\mathrm{M}_{3}$, wear class and age also fits a polynomial regression. In Cazorla, $y=0.3$ $+0.1 x-(2.5 \mathrm{E}-4) x^{2}(F=111.3, \mathrm{df}=2,64, p<0.001)$, and in Gredos, $y=-3.1+0.2 x$ $-(4.2 \mathrm{E}-4) x^{2}(F=87.1, \mathrm{df}=2,44, p<0.001)$. The differences in wear of $\mathrm{M}_{3}$ between 

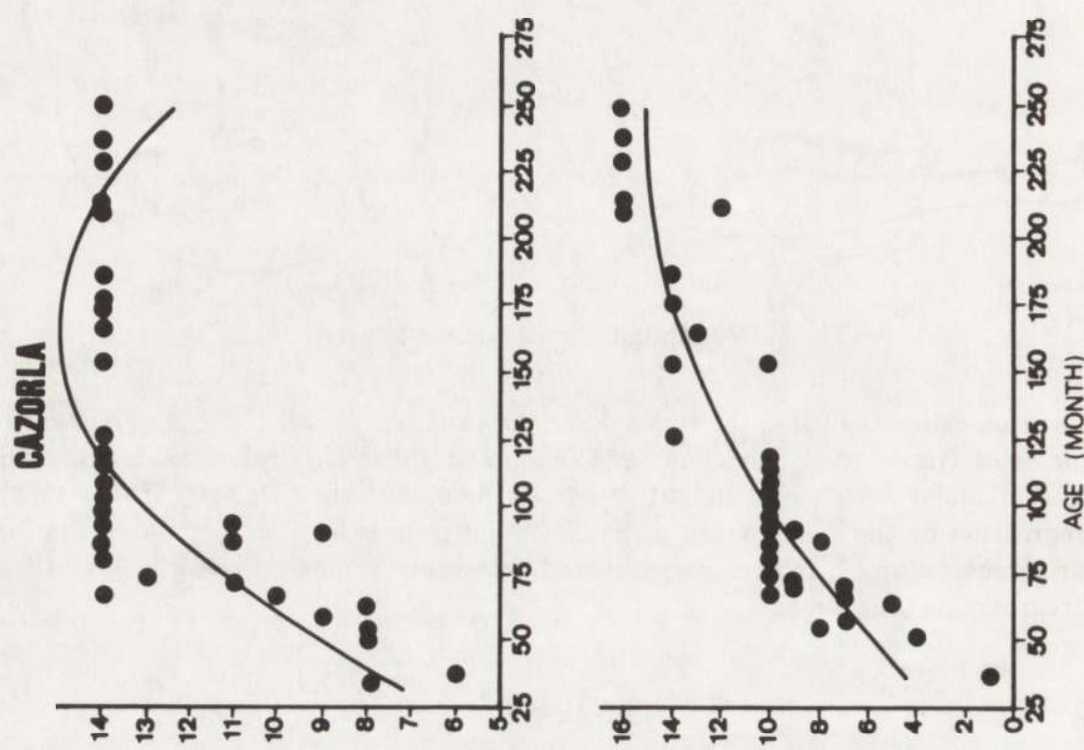

ปี
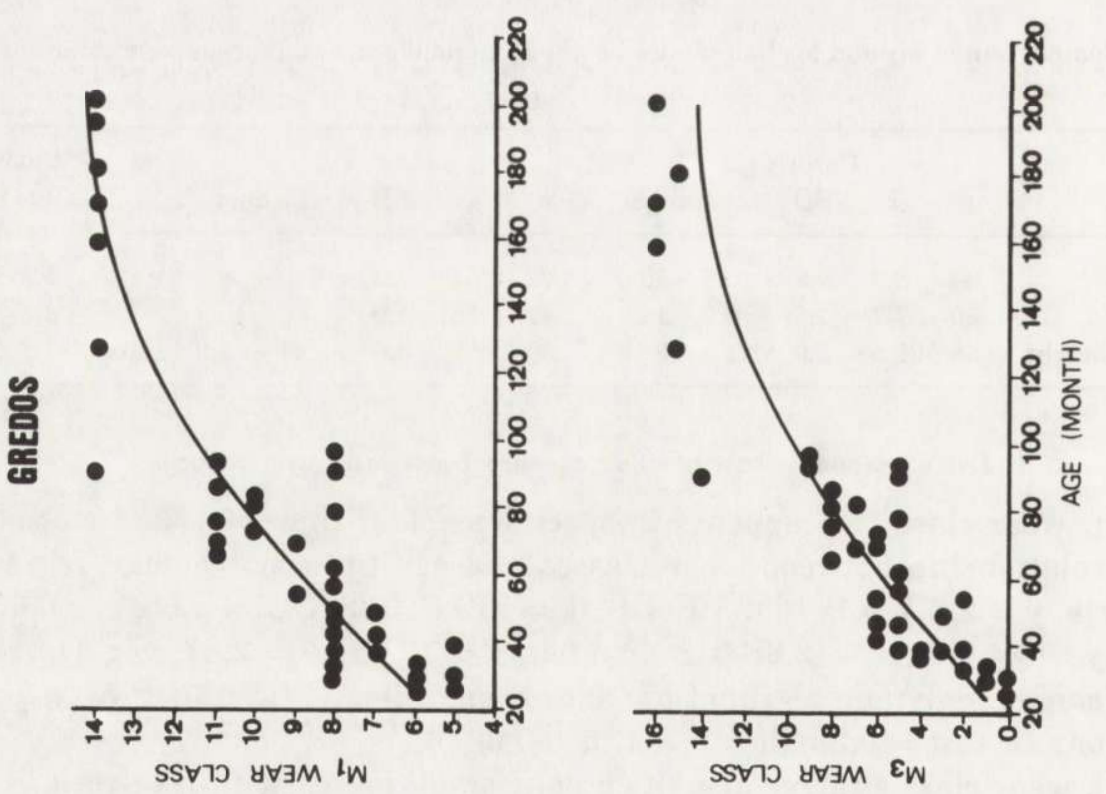

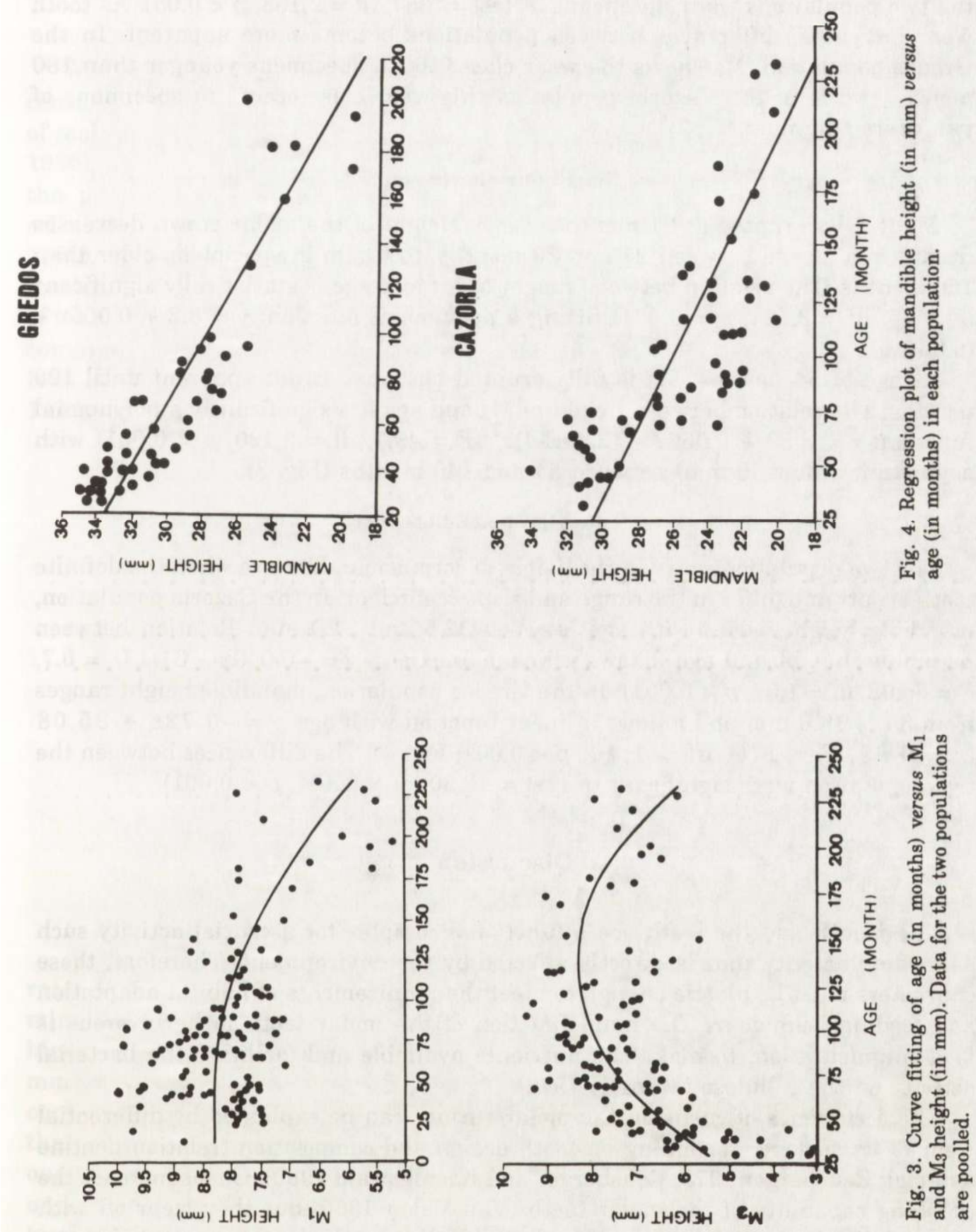
the two populations were significant $(F$ test $=3.57 \mathrm{df}=2,108, p<0.05)$. As tooth wear increases, differences between populations become more apparent. In the Gredos population, $\mathrm{M}_{3}$ shows the wear class " 16 " in specimens younger than 180 months, while in the Cazorla population this wear class occurs in specimens of two years and older.

\section{Height of molar crown}

$M_{1}$ is fully erupted at 21 months of age. Height of the molar crown decreases from $9 \mathrm{~mm}$ at age between 21 and 30 months, to $6 \mathrm{~mm}$ in specimens older than 150 months. The relation between height of $M_{1}$ and age is statistically significant $(F=35, \mathrm{df}=2,124, p=0.001)$ fitting a polynomial function: $y=8.2+0.006 x-$ $(6.86 \mathrm{E}-5) x^{2}$.

At age of 54 months, $M_{3}$ is fully erupted but wear is not apparent until 120 months. The relation between height of $\mathrm{M}_{3}$ and age fits significantly a polynomial function: $y=3.59+0.069 x-(2.48 \mathrm{E}-4) x^{2}(F=49.1, \mathrm{df}=2,120, p=0.001)$ with asymptotic values $(9 \mathrm{~mm}$ ) between 54 and 140 months (Fig. 3).

\section{Height of mandible}

The two populations vary in the height of corpus mandibulare when the definite tooth erupts and differ in the range and slope coefficient. In the Cazorla population, mandible height varies with age between 32.6 and $21.9 \mathrm{~mm}$. Relation between mandible height and age follows a linear function: $y=-0.049 x+31.4(r=0.7$, $F=66.08, \mathrm{df}=1,57, p<0.001$ ). In the Gredos population, mandible height ranges from 35 to $19.6 \mathrm{~mm}$ and follows a linear function with age: $y=-0.72 x+35.08$ $(r=0.89, F=176, \mathrm{df}=1,46, p<0.001$; Fig. 4). The differences between the two population were significant $(F$ test $=13.30, \mathrm{df}=2,104, p<0.001)$.

\section{Discussion}

The mouth and the teeth are a functional complex for a crucial activity such as feeding activity that is directly affected by the environment. Therefore, these characters must be plastic enough to meet the requirements of habitat adaptation and feeding behaviour. The main function of the molar teeth in herbivorous is food fragmentation, to make the nutrients available and facilitate the bacterial activity on the cellulose (Manglio 1972).

The occurrence of cusps on the molar surface can be explained by differential wear of its surface, depending on tooth design and composition (relation dentine /enamel; Rensberger 1973, Rensberger and Koenigswald 1980). Cusps increase the crushing capability of the molar teeth (Van Valen 1960) but they wear off with age and disappear and processing capacity decline as the tooth wear out (Lanyon and Sanson 1986). In the Spanish ibex cusps are worn out after 16 years of age. Thus, older individuals have less ability of fragmentation of the food consumed. 
Differences in molar wear

We found differences between the wear of $M_{1}$ and of $M_{3}$. These differences concern the speed of tooth wear which varies according to molar position, sequence of molar eruption ( $M_{1}$ erupted at 21 months and $M_{3}$ at 54; Vigal and Machordom 1985), and size of the occlusion surface. Size of the occlusion surface influences the proportion of dentine/enamel per surface unit (Van Valen 1960) because cellular position of ameloblasts is a specific character (Lester and Koenigswald 1989). Wear patterns show differences between young and old individuals. Still, tooth wear patterns are reliable age criteria. Nevertheless, for an appropriate use of tooth wear as an age criterion, it is necessary to consider the teeth as a functional complex where wear is affected by the geometry of the jawbone (Fortelius 1985). It is also necessary to examine the whole tooth row (Brown and Chapman 1990, 1991).

Table 2. Composition of the seasonal diet (\%) of Spanish ibex in the Cazorla and Gredos populations. $n$ - sample size, (1) see Martínez et al. (1985), (2) see Martínez and Martínez (1987), (3) see Martínez (1989).

\begin{tabular}{lllccc}
\hline Site & Season & $n$ & Ligneous & Herbaceous & Graminaceous \\
\hline Cazorla & Spring (1) & 22 & 41.26 & 19.79 & 39.00 \\
& Summer (1) & 28 & 60.01 & 18.59 & 21.40 \\
& Autumn (1) & 20 & 66.64 & 11.26 & 22.10 \\
& Winter (1) & 35 & 73.95 & 10.65 & 15.40 \\
Gredos & Spring (2) & 20 & 6.57 & 12.98 & 80.45 \\
& Summer (2) & 20 & 5.80 & 14.06 & 80.14 \\
& Autumn (3) & 20 & 13.25 & 13.21 & 73.54 \\
& Winter (3) & 20 & 16.91 & 13.32 & 69.77 \\
\hline
\end{tabular}

Although the teeth of the two populations follow the same wear pattern, wear rate (measured as the difference between initial (unworn) height in $\mathrm{mm}$ of $\mathrm{M}_{3}$ and minimal height (completely worn) of $\mathbf{M}_{3}$ divided by age maxima in months) is higher in the Gredos $(0.02 \mathrm{~mm} / \mathrm{month})$ than in the Cazorla population $(0.0175$ $\mathrm{mm} / \mathrm{month}$ ). These differences we relate to the different type of food consumed in each population. In the Gredos population, gramineaceous plants represent more than $75 \%$ of the ingested biomass throughout the year whereas in the Cazorla one, this kind of food represents only less than 25\% (Martínez et al. 1985, Martínez and Martínez 1987, Martínez 1989, Table 2). This causes higher abrasion in the teeth due to the siliceous compounds and the different torsion and malleability of this group of plants. The same effect was described for the chamois (Kurtén 1953), and between Mule deer and elk (Spalinger and Robbins 1986). 


\section{Age criteria consequences}

We conclude that the sequential tooth wear patterns are specific characteristics (Butler 1983, Spinage and Brown 1988) but tooth wear is not constant because there is an abrasion process that is dependent of food composition (Morris 1972). Thus, the same wear class can occur at different ages in each population. This finding implies than these must be used the specific age criteria for each population in the species with broad feeding spectra (more than 300 items in the Cazorla population of Spanish ibex; Martínez et al. 1985) and that it is better to use the sequence of tooth replacement or cementum incremental lines as an aging technique instead of wear sequences that is dependent on food composition.

\section{Wear adaptation}

Hypsodontia appears as an evolutionary event involved in the adaptation to the higher tooth wear of herbivores (Van Valen 1960). In the Spanish ibex, the process of molar crown wear might be associated with changes in mandible height. This process might be explained by absortion of jaw material by the teeth through the root or, more likely, by retrogression of the edge of the alveolae. The result of this process would be similar to hypselodontia (Fortelius 1985), compensating the molar crown wear at a lower energetic cost.

Thus, wear patterns (Payne 1987) do not show a linear relation with molar crown height (measured from the edge of the alveolus). There are linear relationships between height of molar crown and mandible height as a cumulative result of two different processes, one mechanical and one physiological and rate of wear (height of the mandible plus the molar crown) would be of $0.065 \mathrm{~mm} / \mathrm{month}$ in the Cazorla population and of $0.122 \mathrm{~mm}$ per month in the Gredos population.

The differences in rate of tooth wear depicted here for the Spanish ibex imply important consequences for the life history of the population. These may include the age of senility of the individual. This relationship was suggested by Flower (1931) who related tooth wear, to longevity and tooth loss, and by Laws (1968) who found that "mechanical senility" was an important mortality factor in very old Hippopotamus amphibius. In this paper we do not focus on this relationship. However, it must be taken into consideration that two populations of the same species can show important differences in the rate of molar wear.

Acknowledgments: We would like to acknowledge to F. Palacios and C. R. Vigal for providing the material for this work, to Unidad de Ecología of the E. B. Doñana for their encouraging support, to S. Reig and R. Márquez for their comments on various drafts of the manuscript, and to all the persons who made this study possible.

\section{References}

Boyde A. and Fortelius M. 1986. Development, structure and function of rhinoceros enamel. Zool. J. Linn. Soc. 87: $181-214$.

Brown W. A. B. and Chapman N. G. 1990. The dentition of fallow deer (Dama dama): a scoring scheme to assess age from wear of the permanent molariform teeth. J. Zool., Lond. 221: 659-682. 
Brown W. A. B. and Chapman N. G. 1991. The dentition of red deer (Cervus elaphus): a scoring scheme to assess age from wear of the permanent molariform teeth. J. Zool., Lond. 224: 519 - 536. Butler P. M. 1972. Some functional aspects of molar evolution. Evolution 26: 474 - 483.

Butler P. M. 1983. Evolution and mammalian dental morphology. Jour. Biol. Buccale 11: 285 - 302.

Caughley G. 1965. Horn rings and tooth eruption as criteria of age in the Himalayan thar, Hemitragus jemlahicus. N. Z. J. Sci. 8: $333-351$.

Coutourier M. 1961. Détermination de l'ge du bouquetin des Alpes (Capra aegagrus ibex ibex) l'aide de dents et des cornes. Mammalia 25: $453-461$.

Chapman D. I. and Chapman N. G. 1970. Development of the teeth and mandibles of fallow deer. Acta theriol. 15: $111-131$.

Fandos P. 1986. Aspectos ecológicos de la población de cabra montés (Capra pyrenaica Schinz, 1838) en las Sierras de Cazorla y Segura (Jaén). Ph. D. thesis, Universidad Complutense, Madrid: $1-475$.

Fandos P. 1991. La cabra montés (Capra pyrenaica) en el Parque Natural de las Sierras de Cazorla, Segura y Las Villas. ICONA. Madrid: $1-176$.

Fandos P., Vigal C. R., Machordom A., Fernandez J. M., Martinez T. and Palacios F. (in press). Horn segments and dental cementum lines as age criteria for the Spanish wild goat. Säugetierk. Mitt.

Flower S. S. 1931. Contributions to our knowledge of life in vertebrate animals. V. Mammals. Proc. Zool. Soc. London: 145 - 234 .

Fortelius M. 1985. Ungulate cheek teeth: developmental, functional, and evolutionary interrelations. Acta zool. Fenn. 180: 1 - 76.

Gordon K. D. 1982. A study of microwear on chimpanzee molars: Implications for dental microwear analysis. Am. J. Phys. Anthrop. 59: 195 - 215.

Gray G. G. and Simpson C. D. 1985. Horn growth and aging of free ranging Barbary sheep (Ammotragus lervia). Mammalia 49: 85 - 91.

Hall-Martin A. J. 1976. Dentition and age determination of the giraffe Giraffa camelopardalis. J. Zool., Lond. 180: $263-289$.

Jachmann H. 1988 Estimating age in African elephants: a revision of Laws' molar evaluation technique. Afr. J. Ecol. 26: $51-56$.

Kay R. F. and Cant J. G. H. 1988. Age assessment using cementum annulus counts and tooth wear in a free-ranging population of Macaca mulatta. Am. J. Primat. 15: 1-15.

Klevezal G. and Kleinenberg S. 1969. Age determination of mammals from annual layers in teeth and bones. IPSt Cat. No. 5433, Jerusalem: $1-128$.

Koenigswald W. von 1992. Tooth amanel of the cave bear (Ursus spelaeus) and the relationship between diet and enamel structures. Ann. zool. Fenn. 28: $217-227$.

Koenigswald W. von, Rensberger J. M. and Pfretzschner H. U. 1987. Changes in tooth enamel of early Paleocene mammals allowing increased diet diversity. Nature 328: 150 - 152 .

Kurtén B. 1953. On the variation and population dynamics of fossil and recent mammal populations. Acta zool. Fenn. 76: $1-122$.

Lanyon J. M. and Sanson G. D. 1986. Koala (Phascolarctos cinereus) dentition and nutrition. II. Implications of tooth wear in nutrition. J. Zool., Lond. 209: 169-181.

Laws R. M. 1968. Dentition and aging of the hippopotamus. E. Afr. Wildlife J. 6: 19-52.

Lester K. S. and von Koenigswald W. 1989. Crystalline orientation discontinuities and the evolution of mammalian enamel, when is a prism?. Scanning Microsc. 3 (2): $645-663$.

Manglio V. J. 1972. Evolution of mastication in the Elephantidae. Evolution 26: 638 - 658.

Martínez T. 1989. Recursos tróficos de la Cabra montés (Capra pyrenaica, Schinz, 1838) en la Sierra de Gredos, durante Otoño e Invierno. Ecología 3: 179 - 186.

Martínez T. and Martínez E. 1987. Diet of the Spanish wild goat, Capra pyrenaica, in spring and summer at the Sierra de Gredos, Spain. Mammalia 52: 347 - 357.

Martínez T., Martínez E. and Fandos P. 1985. Composition of the food of the Spanish wild goat in Sierras de Cazorla and Segura, Spain. Acta theriol. 30: 461 - 494. 
McNaughton S. J. 1984. Grazing lawns: Animals in herds, Plant form and coevolution. Am. Nat. 124: $863-886$.

Miller F. L. 1974. Biology of the Kaminuriak population of barren-ground caribou. Part 2. Canadian Wildlife Service Reports Series 31: $1-87$.

Morris P. 1972. A review of mammalian age determination methods. Mammal Rev. 2: 69 - 104.

Norton P. M. and Fairall N. 1991. Mountain reedbuck Redunca fulvorula growth and age determination using dentition. J. Zool., Lond. 225: 293 - 307.

Payne S. 1973. Kill-off patterns in sheep and goats: the mandibles of Asvan Kale. Anatolian Studies 23: $281-303$.

Payne S. 1987. Reference codes for wear states in the mandibular cheek teeth of sheeps and goats. J. Archaeol. Sci.14: 609 - 614.

Rensberger J. M. 1973. An occlusion model for mastication and dental wear in herbivorous mammals. J. Paleont. 47: $10-22$.

Rensberger J. M. and von Koenigswald W. 1980. Functional and phylogenetic interpretation of enamel microstructure in rhinoceroses. Paleobiology 6: $447-495$.

Skogland T. 1988. Tooth wear by food limitation and its life history consequences in wild reindeer. Oikos 51: $238-242$.

Spinage C. A. and Brown W. A. B. 1988. Age determination of the west African buffalo Syncerus caffer brachyceros and the constancy of tooth wear. Afr. J. Ecol. 26: 221 - 227.

Spalinger D. E. and Robbins C. T. 1986. The assessment of handling time in ruminates: the effect of plant chemical and physical structure on the rate of breakdown of plant particles in the rumen of mule deer and elk. Can. J. Zool. 64: $312-321$.

Teaford M. F. 1982. Differences in molar wear gradient between juvenile macaques and langurs. Am. J. Phys. Anthrop. 57: $323-330$.

Valen L. van 1960. A functional index of hypsodonty. Evolution 14: $531-532$.

Vigal C. R. and Machordom A. 1985. Tooth eruption and replacement in the Spanish wild goat. Acta theriol. 30: $305-320$.

Vigal C. R. and Machordom A. 1987. Dental and skull anomalies in the Spanish wild goat, Capra pyrenaica Schinz, 1838. Z. Säugetierk. 52: $38-50$.

Walker A., Hoeck H. N. and Perez L. 1978. Microwear of mammalian teeth as an indicator of diet. Science 201: $908-910$.

Zar J. H. 1984: Biostatistical analysis. Prentice-Hall, Inc., Englewood Cliffs, New Jersey: 1 - 718.

Received 9 October 1992, accepted 1 February 1993. 